\title{
Distributed hydrological modeling of total dissolved phosphorus transport in an agricultural landscape, part II: dissolved phosphorus transport
}

\author{
W. D. Hively ${ }^{1}$, P. Gérard-Marchant ${ }^{2}$, and T. S. Steenhuis ${ }^{2}$ \\ ${ }^{1}$ Department of Natural Resources, Cornell University, Ithaca, NY 14853, USA \\ ${ }^{2}$ Soil \& Water Group, Department of Biological and Environmental Engineering, Riley Robb Hall Cornell University, Ithaca, \\ NY 14853, USA
}

Received: 1 July 2005 - Published in Hydrol. Earth Syst. Sci. Discuss.: 22 August 2005

Revised: 6 December 2005 - Accepted: 21 February 2006 - Published: 26 April 2006

\begin{abstract}
Reducing non-point source phosphorus (P) loss to drinking water reservoirs is a main concern for New York City watershed planners, and modeling of $\mathrm{P}$ transport can assist in the evaluation of agricultural effects on nutrient dynamics. A spatially distributed model of total dissolved phosphorus (TDP) loading was developed using raster maps covering a 164-ha dairy farm watershed. Transport of TDP was calculated separately for baseflow and for surface runoff from manure-covered and non-manure-covered areas. Soil test $P$, simulated rainfall application, and land use were used to predict concentrations of TDP in overland flow from non-manure covered areas. Concentrations in runoff for manure-covered areas were computed from predicted cumulative flow and elapsed time since manure application, using field-specific manure spreading data. Baseflow TDP was calibrated from observed concentrations using a temperaturedependent coefficient. An additional component estimated loading associated with manure deposition on impervious areas, such as barnyards and roadways. Daily baseflow and runoff volumes were predicted for each 10-m cell using the Soil Moisture Distribution and Routing Model (SMDR). For each cell, daily TDP loads were calculated as the product of predicted runoff and estimated TDP concentrations. Predicted loads agreed well with loads observed at the watershed outlet when hydrology was modeled accurately $\left(\mathrm{R}^{2} 79 \%\right.$ winter, $87 \%$ summer). Lack of fit in early spring was attributed to difficulty in predicting snowmelt. Overall, runoff from non-manured areas appeared to be the dominant TDP loading source factor.
\end{abstract}

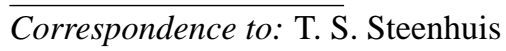
(tss1@cornell.edu)

\section{Introduction}

Water quality protection programs require the effective control of non-point source (NPS) pollution. Phosphorus (P) has been recognized as a key element controlling surface water eutrophication (Carpenter et al., 1998), and legislative measures have been taken to encourage the reduction of $\mathrm{P}$ loading on a watershed scale. In the New York City watersheds, maintaining low phosphorus levels is a challenge for the economic development of local communities. Phosphorus loss from dairy farms has been identified as a significant contributor of non-point-source $\mathrm{P}$ loading to Cannonsville Reservoir (Brown et al., 1989), the third largest of the reservoirs that supply New York City's drinking water. The New York City Watershed Agriculture Program has undertaken a program of Whole Farm Planning and Best Management Practice (BMP) implementation to reduce NPS pollution from regional dairy farms.

Modeling of P loss from watersheds is key to understanding the long term effects of agricultural BMPs (Sharpley et al., 2002). Once the significant mechanisms affecting the fate of soil $\mathrm{P}$ and its release to streams are identified, their relative importance can be estimated and cost-effective preventive or remediatory management practices can be efficiently selected.

The fate and transport of $\mathrm{P}$ in the soil environment has been shown to be responsive to a broad range of abiotic and biotic processes (Frossard et al.,2000), including: soil test $P$ (Cox and Hendricks, 2000; McDowell and Sharpley, 2001); landuse (Beauchemin et al., 1996); tillage (Kingery et al., 1996); soil mineralogy and particle size distribution (Cox and Hendricks, 2000); erosion (Sharpley et al., 2002); manure application (Beauchemin et al., 1996; Kleinman et al., 1999;

Published by Copernicus GmbH on behalf of the European Geosciences Union. 
Kleinman and Sharpley, 2003); grazing (Smith and Monaghan, 2003); plant uptake (Koopmans et al., 2004); P mass balance and soil accumulation (Cassell et al., 1989); soil moisture and hydrology (McDowell and Sharpley, 2002b); soil type (Needelman et al., 2004) and management (Ginting et al., 1998; Klatt et al., 2003; Sharpley and Kleinman, 2003); temperature and precipitation (Correll et al., 1999); sorption kinetics (Morel et al., 2000; Schoumans and Groenendijk, 2000); and preferential flow and soil structure (Akhtar et al., 2003).

Basically, phosphorus can be transported as particulate $\mathrm{P}$, through erosion, or as dissolved $\mathrm{P}$ through leaching and overland flow. Traditionally, control of particulate $\mathrm{P}$ in runoff has been considered sufficient to improve water quality (Sharpley et al., 1994). However, recent research has shown that particulate $\mathrm{P}$ has a much smaller effect on eutrophication levels than dissolved P (Fozzard et al., 1999). This paper focuses only on the transport of total dissolved P (TDP).

The complexity of simulating $\mathrm{P}$ loading processes that vary spatially, temporally, and with management practices is amazing. A mechanistic modeling of the interaction of TDP with the environment would require an extensive set of input parameters which are not readily available. Therefore, a reasonable simplification consists in lumping the different biotic and abiotic processes, so that $\mathrm{P}$ loss is modeled using an export coefficient approach (Clesceri et al., 1986; Hanrahan et al., 2001; Sharpley et al., 2002), where flow volumes are combined with predicted $\mathrm{P}$ concentrations that are derived from soil-, environment-, and site-specific data. Such a lumped approach has the advantage of reducing the required number of parameters, thus limiting the risk of over parametrization described by Beven (1996), among others.

In order to apply the export coefficient approach, insight into the generation mechanisms of overland flow is needed (Gburek et al., 1996). Two main processes can be considered. Infiltration-excess overland flow occurs when rainfall intensity exceeds soil infiltration capacity (Horton, 1933, 1940). The resulting runoff volume generated depends on rainfall intensity, soil type and land cover. In the case of infiltration-excess runoff production, semi-distributed models, such as SWAT (Arnold et al., 1993, 1994; Neitsch et al., 2002; DiLuzio and Arnold, 2004) or GWLF (Haith and Shoemaker, 1987; Haith et al., 1992; Schneiderman et al., 2002), are sufficient to estimate streamflows and TDP loads. In contrast, saturation excess overland flow is generated by precipitation falling on already saturated areas, or when subsurface flows converge in an poorly drained area (Hewlett and Hibbert, 1967; Dunne and Black, 1970; Hewlett and Nutter, 1970; Dunne et al., 1975; Beven and Kirkby, 1979). Runoff volumes are then a function of topography and soil characteristics. In this case, fully distributed models preserving information about landscape position must be used. In addition, $\mathrm{P}$ loading processes are spatially heterogeneous, requiring the distributed estimation of above and below ground flow volumes and P loading pathways. In the Catskills re- gion, where saturation-excess is the dominant process for runoff production, a fully distributed modeling approach is required to adequately characterize overland flow production from source areas that vary spatially and temporally.

Spatially-distributed hydrological modeling of small, upland watersheds is possible using the Soil Moisture Distribution and Routing model (SMDR). In SMDR, the watershed is divided into a continuous grid of square cells of 10 to $30 \mathrm{~m}$ side. At each time step, a water balance is computed on each gridcell of the watershed. Overland flow is generated mainly by saturation excess. Infiltration excess is taken into account on impervious areas such as roads and barnyards. Details of the water balance components are presented in a companion to this paper (Gérard-Marchant et al., 2006). The model has been successfully applied to several New York and Pennsylvania watersheds (Frankenberger et al., 1999; Kuo et al., 1999; Johnson et al., 2003; Mehta et al., 2004; Srinivasan et al., 2005). The model is designed to simulate sloping areas, and does not work in flatter areas such as alluvial floodplains, nor does it account for infiltration excess runoff that can be produced on dry soils by brief, intense summer rainstorms.

The objective of this paper is to develop and test a fully distributed model that can predict total dissolved P (TDP) transport from small watersheds where saturation-excess runoff production is the dominant hydrological process.

\section{Description of the total dissolved $P$ transport model}

Four transport processes are considered in the various model components of the SMDR TDP load model: (i) TDP loss from non-manure covered soils in overland flow, (ii) TDP loss in base flow, (iii) TDP loss from manure-covered areas in overland flow, and (iv) TDP loss from impervious areas (roads, farmstead). The four processes are modeled separately, on a daily basis, for each gridcell, and summed to estimate daily TDP loads from the entire watershed.

\subsection{Component 1. Overland Flow from non Manure- covered Soils}

Management history, including manure and nutrient application, crop removal, and tillage, can have a significant effect on soil P content, with repeated manure application leading to nutrient accumulation and increased risk of leaching. Sharpley et al. (1996); Maguire and Sims (2002) and McDowell and Sharpley (2003), among others, have demonstrated that TDP concentrations in overland flow and in baseflow are positively correlated to the quantity and extractability of $\mathrm{P}$ in the top layer of soil. Although more complex relationships have been suggested (Kleinman et al., 2000; McDowell and Sharpley, 2001), a simple linear relationship between soil test $P$ and TDP in runoff is generally valid for soils with $\mathrm{P}$ concentrations below a critical $\mathrm{P}$ saturation threshold 
(Kleinman et al., 1999; Sharpley et al., 2002), and can be expressed as:

$D_{<S>}(t)=\mu S T P(t) S E(t)$

where $D_{<S>}$ is the loss of TDP in overland flow per unit area $\left[\mathrm{kg} \mathrm{m}^{-2}\right], S T P$ the amount of extractable soil $\mathrm{P}$ as estimated by soil test $\mathrm{P}\left[\mathrm{kg} \mathrm{m}^{-3}\right], S E$ the overland flow volume per unit cell area $\left[\mathrm{m}^{3} \cdot \mathrm{m}^{-2}\right]$, and $\mu$ a soil-specific coefficient determined from rainfall simulation (Schroeder et al., 2004) or laboratory extraction (Beauchemin et al., 1996; Pote et al., 1996) at a specific temperature. Equation (1) can be simplified to:

$D_{<S>}(t)=c_{S}(t) S E(t)$

where $c_{S}(t)=\mu S T P(t)$ is the TDP export coefficient $\left[\mathrm{kg} \mathrm{m}^{-3}\right]$, corresponding to the average predicted TDP concentration in runoff from a particular cell. This coefficient depends thus partly on soil properties, through the coefficient $\mu$, and partly on land use and management practices that affect the concentration of $\mathrm{P}$ in soils, STP. Potential release of TDP from soils, as reflected in the export coefficient, depends on both abiotic factors (soil moisture, temperature, precipitation, de/sorption and transport), and biotic factors (decomposition, mineralization, plant uptake) that vary with climate and season (Frossard et al., 2000; Hansen et al., 2002).

In order to reflect the temporal nature of TDP availability, the export coefficients associated with each combination of soil and land use are modified with an Arrhenius type of equation (Bunnell et al., 1977; Johnsson et al., 1987; Kuo, 1998):

$c_{S}(t)=c_{\text {Sref }} Q_{S}^{\left[\frac{T(t, 0)-T_{S}}{10}\right]}$

where $T(t, 0)$ is the mean temperature at the soil surface at time $\mathrm{t}\left[{ }^{\circ} \mathrm{C}\right], T_{S}$ the base temperature at which the reference export coefficient $c_{\text {Sref }}$ was estimated $\left[{ }^{\circ} \mathrm{C}\right]$, and $Q_{S}$ the factor change (range 1 to 5 ) for a $10^{\circ} \mathrm{C}$ change in temperature. Soil surface temperatures can be approximated from long term climate records, as

$T(t, 0)=T_{\mathrm{avg}}+\Delta T \sin \left[\omega\left(t-t_{\phi}\right)\right]$

where $T_{\text {avg }}$ is the annual average temperature of the soil surface $\left[{ }^{\circ} \mathrm{C}\right], \Delta \mathrm{T}$ the maximum temperature deviation from the annual average $\left[{ }^{\circ} \mathrm{C}\right], \omega=2 \pi / 365$ the radial frequency $\left[\mathrm{d}^{-1}\right]$ and $t_{\phi}$ a lag time [d] so that $\omega t=t_{\phi}$ when $T(t, 0)=T_{a v g}$.

\subsection{Component 2. Baseflow}

Although transport in overland flow is the predominant $\mathrm{P}$ loading mechanism in many watersheds (Randall et al., 2000), subsurface transport can often be substantial (Maguire and Sims, 2002; Ryden et al., 1973). In particular, soils exhibiting preferential flow through macropores can quickly transport a significant amount of $\mathrm{P}$ to deeper soils (Gächter et al., 1998; Stamm et al., 1998; Gupta et al., 1999; Akhtar et al., 2003) and to subsurface drains (Hooda et al., 1999; Geohring et al., 2001). Baseflow chemistry has been shown to vary temporally and spatially with changes in land use, representing an integrated signal of climate, geology, and historical land use (Wayland et al., 2003).

Once again, the complexity of mixing and equilibrium interactions between $\mathrm{P}$ forms in the soil and soil-water solution advocates implementing an export coefficient approach. Loads of TDP in baseflow D $\left[\mathrm{kg} \mathrm{d}^{1}\right]$ are thus calculated as:

$D_{<B F>}(t)=c_{B F} B F(t) A$

where $c_{B F}$ is the baseflow export coefficient $\left[\mathrm{kg} \mathrm{m}^{-3}\right]$, $B F(t)$ the predicted daily baseflow volume delivered over the watershed (per unit area) $\left[\mathrm{m}^{3} \mathrm{~m}^{-2} \mathrm{~d}^{-1}\right]$, and $A$ is the watershed area $\left[\mathrm{m}^{2}\right]$.

Seasonal variability of the baseflow export coefficient $c_{B F}$ is modeled similarly to the soil export coefficient $c_{S}$, as :

$c_{B F}(t)=c_{B F \text { ref }} Q_{B F}^{\left[\frac{T(t)-T_{B F}}{10}\right]}$

where $Q_{B F}$ and $T_{B F}$ are two calibration parameters. The difference with Eq. (3) is that base flow originates from deeper in the soil, and therefore uses an estimated below-ground soil temperature. The soil temperature at a depth $z_{T}[\mathrm{~m}]$ is calculated assuming that the annual surface temperature varies as a sine wave (de Vries, 1963; Brutsaert, 1982):

$T\left(t, z_{T}\right)=T_{a v g}+\Delta T e^{-z_{T} / z_{e}} \sin \left[\omega\left(t-t_{\phi}\right)-z_{T} / z_{e}\right]$

where $z_{e}$ the equivalent damping depth [m], which is directly related to thermal diffusivity. It should be noted that the baseflow export coefficient $c_{B F}$ is calculated for the entire watershed, rather than on a gridcell basis, and should be calibrated from observed base flow streamwater concentrations of TDP. This direct calibration also serves to account for in-stream processes particular to the watershed, including in-stream manure deposition, stream bank erosion, algal growth, and the effects of hydric soils and sediments. This approach is consistent with the assumption in the hydrology model that all the water percolating out of the topsoils enters a subsurface reservoir. Ideally one would link P concentration in the baseflow directly to the average DP concentration of the percolating water or to the soil TDP export coefficients. These processes are currently being investigated but results are not conclusive yet. Therefore, for this paper, simulated DP baseflow concentrations are calibrated with observed DP values.

\subsection{Component 3. Overland Flow from Manure-Covered Areas}

Surface application of manure can lead to large TDP losses in overland flow (e.g., Sharpley et al., 1998; Haygarth and Sharpley, 2000; Kleinman, 2000) if the nutrients are not incorporated and runoff production is large. In some circumstances, $\mathrm{P}$ loading from manured areas can be several orders 
of magnitude larger than loads produced from non-manured soils (Edwards and Daniel, 1993b). The SMDR TDP model calculates TDP losses from surface applied manure using an extraction coefficient approach, where the coefficient is modified by cumulative runoff and elapsed time since manure application, on a semi-distributed basis.

Sharpley and Moyer (2000) observed from laboratory experiments that the concentration of manure TDP (both organic and inorganic forms) in leachates decreased rapidly during simulated rainfall events. A re-examination of their data shows that during a rainfall event of duration $\delta t[\mathrm{~d}]$ with an average rainfall rate $R\left[\mathrm{~m}^{3} \mathrm{~m}^{-2} \mathrm{~d}^{-1}\right]$, the load of TDP leached from manure, $D_{<M>}(\delta t)$, can be expressed as (Gérard-Marchant et al., 2005):

$D_{<M>}(\delta t)=M(t) \exp \left(-k_{D} \delta V / R\right)$

where $M(t)$ is the amount (per unit area) of water-extractable $\mathrm{P}$ available in manure at time $t\left[\mathrm{~kg} \mathrm{~m}^{-2}\right], k_{D}$ the reaction constant $\left[\mathrm{d}^{-1}\right]$, and $\delta V=\delta t / R$ is the volume of precipitation during the time interval $\delta t$.

Gérard-Marchant et al. (2005) did not observe any clear correlation between the reaction constant $k_{D}$ and simulated rainfall rate. Therefore, it can be assumed in a first approximation that the ratio $k_{D} / R$ is independent of time and rainfall rate, so that in Eq. (8), the event duration $\delta t$ can be replaced by the time step $\Delta t$, the volume $\delta V$ by the volume of runoff (per unit cell area) generated during the time step, $\Delta V$, and the ratio $k_{D} / R$ by a constant characteristic volume $V_{m}$. Equation (8) then becomes:

$D_{<M>}(\Delta t)=M(t)\left[1-\exp \left(-\Delta V / V_{m}\right)\right]$.

If no runoff is generated on the cell during the time step, the volume $\Delta V$ is identified with the amount of rainfall or snowmelt, but $D_{<M>}$ does not contribute to stream loads.

After application, manure $\mathrm{P}$ interacts with soil between rainfall events and is transformed to forms less and less available for transport (Edwards and Daniel, 1993a). Based on the findings of Gascho et al. (1998) and Nash et al. (2000), the decline in availability of manure water-extractable $\mathrm{P}, M$, is modeled as an exponential decay:

$M(t)=M\left(t_{o}\right) \exp \left[-\left(t-t_{o}\right) / \tau\right]$

where $M\left(t_{o}\right)$ is the initial content of water-extractable $\mathrm{P}$ in manure applied at time $t_{o}$, and $\tau$ the characteristic decay time [day]. For lack of additional data, $\tau$ is considered a constant, independent of temperature.

A fully distributed modeling requires knowledge not only of the amount of manure applied, but also of the location and method of the application. Unfortunately, the location information is usually not available on a gridcell basis, and a semi-distributed approach must be followed. The watershed is divided in "manure application zones", corresponding to the smallest area for which information about manure application is available, such as a field, or a group of adjacent fields. Each manure application zone is then subdivided in elementary "spreading plots", with an area equal to that covered with a single load of manure. At each time step, manure is first distributed on each application zone following farmer's information, then randomly on each spreading plot within each application zone, so that no plot can receive manure again before all plots of the zone are covered. Manure TDP losses in runoff are then computed with Eqs. (9) and (10) for each spreading plot, using precipitation data and saturation excess overland flow volumes simulated by SMDR. The simulated overland flow is averaged over each manure application zone, i.e., each spreading plot of one zone receives the average of the estimated runoff volumes for the gridcells within each manure application zone.

\subsection{Component 4. Impermeable areas}

Overland flow from heavily-manured impervious source areas, including barnyards, roadways, and cowpaths, can play a significant role in delivering water and TDP to the stream (Robillard and Walter, 1984; McDowell and Sharpley, 2002a; Hively, 2004), particularly during dry summer periods when the extent of saturated soils is small. Ideally, TDP loads in overland flows from manure-covered impervious areas could be simulated using the same approach as for manure-covered soils described in Eq. (9). However, the temporal dynamics of barnyard and roadway $\mathrm{P}$ availability are not yet well characterized. Therefore, a more generic "export coefficient" approach is followed, similar to the modeling of TDP release from soils to overland flow. The overall extents of manured and non-manured impervious areas are estimated from fine-scale land use mapping and an equivalent number of gridcells are established as impervious, with extraction coefficients chosen for periods of active grazing (spring to fall) and animal confinement (winter).

It could be argued that shallow lateral transport of $\mathrm{P}$ in the vadose zone is an important factor that should be modeled explicitly. However, the spatial heterogeneity of macropore flow processes makes this inherently difficult. Although the SMDR model does route water horizontally in the vadose zone, it was elected to confine the $\mathrm{P}$ routing model to the aforementioned four pathways because there is no data available to independently verify $\mathrm{P}$ concentrations in macropore flow. Furthermore, water transported horizontally through macropores can be expected to have one of four possible fates: 1) percolation into the subsoil, 2) contact with tile drainage, 3) conversion to surface runoff in the form of seepage and springs, and 4) direct transport into the stream channel. In the case of percolation, this is accounted for in the baseflow component. Tile drainage, however, might be a confounding factor. During grabsampling of runoff on the study watershed (Hively, 2004) P concentrations in flow from tile drains were consistently elevated in comparison to concentrations observed in overland flow from field areas. 
Additional work that was done on the farm (Scott et al., 1998) observed that approximately $1 / 3$ of total annual P lost from a grazed pasture was transported through tile drains. Accordingly, it might be worth while to attempt to incorporate tile drainage pathways into future versions of the model. In the case of conversion to surface runoff, which we believe to be the dominant fate of vadose zone macropore flow, this will tend to occur at slope breaks, toe slopes, and areas of converging groundwater flow pathways. In this case, it is assumed that soil $\mathrm{P}$ concentrations and land use at the point of surface runoff production control the concentration of $\mathrm{P}$ in runoff, as accounted for in the overland flow model component. It is worth while to note, however, that hydrologically active areas such as springs have unique $\mathrm{P}$ source area properties, related in part to the frequency of runoff production (Hively et al, 2005). Unfortunately, simulating the spatial distribution of permanent wet areas consisting of springs originating from faults in the bedrock is only possible with prohibitively intensive data collection. Finally, in the case of direct flow from the vadose zone into the stream, this is expected to comprise a small portion of the total flow from the watershed, and it is accounted for by the calibrated baseflow concentration used in the model.

\section{Input data and parameter estimation}

The SMDR model and the SMDR TDP transport model were applied to a 164-ha rural watershed that hosts a thirdgeneration dairy farm with approximately 80 milking cows and 35 replacement heifers. The study watershed is located in the Catskills region of New York State, within the Cannonsville Reservoir basin. Since 1993, the study watershed has been the subject of a long term monitoring study conducted by the New York State Department of Environmental Conservation (Bishop et al., 2003) that demonstrated a 43\% reduction in TDP loads delivered during runoff events since the implementation of BMPs in 1995 (Bishop et al., 2005). The extensive stream quality dataset and detailed management records available for this farm provided an ideal context for application of the models and verification of results. A detailed description of the study watershed, and a description of the raster maps for land use, soil type, and manure spreading zones, are given in Bishop et al. (2003, 2005), GérardMarchant et al. (2006), and Hively (2004). Total dissolved P (TDP) is defined as molybdate reactive orthophosphate found in filtered (45 um) digested (Kjeldahl) water samples. The SMDR model was applied to the study watershed for a ten year period (1 January 1993-31 October 2001) of input data. The calibration process and validation results of this model are presented in a companion paper (Gérard-Marchant et al., 2006). Manure application records were available for a two year period (1997-1998) and the TDP transport model was therefore applied for the same two year period only.

\subsection{Climate}

The climate of the study area is humid continental, with an average temperature of $8^{\circ} \mathrm{C}$. Annual average precipitation for the year is $1120 \mathrm{~mm}$. Daily minimum and maximum temperatures were obtained from a nearby weather station located at Delhi, New York, 438.9 msl, (National Weather Service (USDC NOAA) cooperative observer station \#302036, "Delhi 2 SE"), located about $20 \mathrm{~km} \mathrm{SW}$ of the site (NCDC, 2000). Temperatures were corrected by $-1.2^{\circ} \mathrm{C}$ to account for the difference in elevation from the study watershed.

\subsection{Land use}

A spatially justified aerial photograph provided the basemap for on-screen digitization of land cover, manure application zones, impermeable areas, streams, artificial drainage, and other important landscape features (Hively, 2004). Combination of this information with field observations, field collection of GPS data, farm planning records, and farmer interview provided sufficient detail to produce 10-m land use raster maps reflecting annual changes in crop rotation. The resulting land use maps for 1997 and 1998 are presented in Fig. 1.

On-site GPS data collection (Hively, 2004) was used to map the extent of manured and non-manured impermeable areas within the watershed. Because the scale of the impermeable features was not adequately captured by the translation to 10-m gridcells, the area of each impermeable landuse type was first calculated, and the landuse raster map was subsequently hand-edited to reflect appropriate area distribution of each near-barn source area type.

\subsection{Observed streamflow and chemistry}

Daily stream flows were recorded on a 10-min basis by a gauge on the watershed outlet, and integrated over a day. Observed TDP concentrations were derived from flow-weighted automated sampling at the watershed outlet, as described in Bishop et al. (2003).

\subsection{Parameters estimation and calibration}

The parameters that must be estimated for the TDP transport models are: export coefficients $c_{\text {Sref }}$ for each combination of soil and land use (Eq. 3); base temperature $T_{s}$ and $Q_{s}$ coefficients (Eq. 3); reference base flow concentration over the watershed $c_{B F \text { ref }}$ (Eq. 6); base temperature $T_{B F}$ and $Q_{B F}$ coefficient (Eq. 6); initial TDP mass in manure $M\left(t_{o}\right)$ per load (Eq. 10); manure decay time $\tau$ (Eq. 10); and manure characteristic volume $V_{m}$ (Eq. 9). As detailed below, most of these parameters are estimated a priori from field measurements or data reported in the literature. However, some parameters are obtained a posteriori by calibration. Values of the parameters are summarized in Table 1. 
Table 1. Model parameter values.

\begin{tabular}{rlrrl}
\hline \multicolumn{1}{c}{ Parameter } & Eq. & Value & \\
\hline Parameters estimated a priori & & & \\
$T_{\text {avg }}$ & Annual average temperature & $(4)$ & 6.3 & {$\left[{ }^{\circ} \mathrm{C}\right]$} \\
$\Delta \mathrm{T}$ & Annual temperature amplitude & $(4)$ & 12.8 & {$\left[{ }^{\circ} \mathrm{C}\right]$} \\
$t_{\phi}$ & Time lag (from Jan., 01) & $(4)$ & 113 & {$[\mathrm{~d}]$} \\
$T_{S}$ & Reference temperature, soil & $(3)$ & 19.1 & {$\left[{ }^{\circ} \mathrm{C}\right]$} \\
$T_{B F}$ & Reference temperature, baseflow & $(6)$ & 15.6 & {$\left[{ }^{\circ} \mathrm{C}\right]$} \\
$z_{e}$ & Annual damping depth & $(7)$ & 1.87 & {$[\mathrm{~m}]$} \\
$z_{T}$ & Average depth to low-permeability layer & $(7)$ & 0.6 & {$[\mathrm{~m}]$} \\
$M\left(t_{o}\right)$ & Initial amount of water-extractable P & $(9)$ & 14 & {$\left[\mathrm{~kg} \mathrm{ha}^{-1} \mathrm{load}^{-1}\right]$} \\
$\tau$ & Exponential decay characteristic time & $(10)$ & 7 & {$[\mathrm{~d}]$} \\
$V_{m}$ & Manure TDP release characteristic volume & $(9)$ & 25 & {$\left[\mathrm{~m}^{3} \mathrm{~m}^{-2}\right]$} \\
& & & & \\
Parameters estimated a posteriori & $(3)$ & 1.5 & {$[-]$} \\
$Q_{S}$ & Q10 base coefficient, soil & $(6)$ & 60 & {$\left[\mu \mathrm{gl}^{-1}\right]$} \\
$c_{B F r e f}$ & Baseflow reference export coefficient & $(6)$ & 2.5 & {$[-]$} \\
$Q_{B F}$ & Q10 base coefficient, baseflow & & & \\
\hline
\end{tabular}
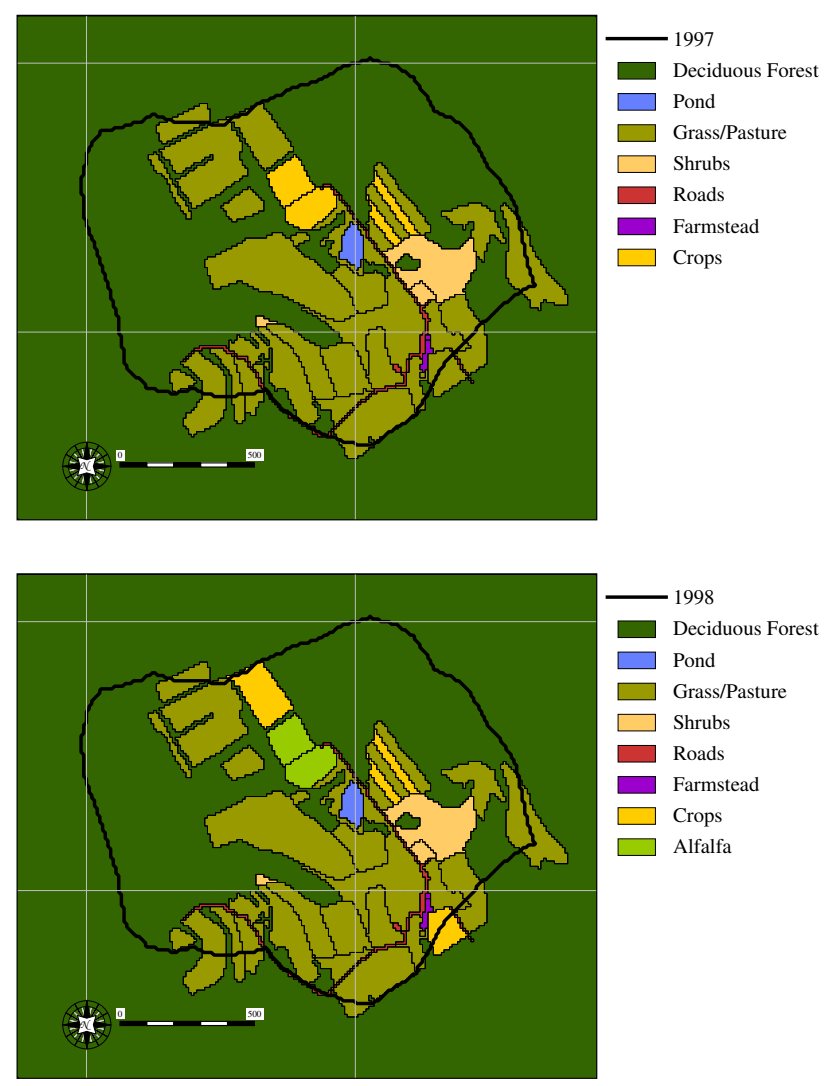

Fig. 1. Land uses and field boundaries for 1997 (top) and 1998 (bottom).
Concentrations of TDP in overland flow were measured using simulated rainfall application at nine locations within the study watershed (Hively et al., 2005). The observed concentrations, $c_{\text {Sobs }}\left[\mathrm{mg}^{-1}\right.$ ] were found to correlate well to Morgan's soil test P (Lathwell and Peech, 1965) for soils with low to moderate soil test $\mathrm{P}\left[c_{\text {Sobs }}=0.0056+0.0180 \mathrm{STP}\right.$, adjusted $\left.\mathrm{R}^{2}=0.84\right]$ and for manured areas exhibiting excessively high soil test $\mathrm{P}\left[c_{\mathrm{Sobs}}=0.4735+0.0065 \mathrm{STP}\right.$, adjusted $\left.\mathrm{R}^{2}=0.84\right]$. These equations, in combination with soil test $\mathrm{P}$ data collected throughout the watershed, provided initial estimations of TDP export coefficients for overland flow from non-manured soils. These values were subsequently rounded and adjusted to reflect TDP concentrations observed in samples of overland flow and other data collected on the study farm (Hively, 2004). When soil test $P$ data were not available for a field, a TDP export coefficient was assigned by comparison with other fields sharing the same management history. Export coefficients were also estimated for impervious areas, such as barnyard and roadways, from the relationship derived for high soil test $P$ soils, subsequently modified to reflect TDP concentrations observed in grabsamples of surface runoff during rainfall and snowmelt events (Hively, 2004). Eventually, a 10-m raster map gathering all this information was produced, so that each land use category was assigned an estimated TDP release concentration $c_{\text {Sref }}$. The resulting map is presented Fig. 2.

Annual average temperature $T_{\text {avg }}$, temperature deviation $\Delta T$, and time lag $t_{\phi}$ in Eq. (4) were estimated a priori from monthly averages of minimum, maximum and mean temperatures obtained for a 80-year period (1924-2004) from the Delhi, NY weather station. The reference temperature $T_{S}$ for the soil export coefficient in Eq. (3) was set a priori to the amplitude of the sine wave temperatures at the soil 
surface $\left(20^{\circ} \mathrm{C}\right)$. The parameter $Q_{s}$ for soil export coefficients introduced in Eq. (3) was obtained a posteriori by calibration with observed TDP loads. The parameters $c_{B F \text { ref }}$ and $Q_{B F}$ of the baseflow export coefficient, Eq. (6), were also obtained a posteriori by calibration for winter and summer low flow events. The equivalent annual damping depth introduced in Eq. (7) to compute soil temperatures was set a priori to $z_{e}=1.87 \mathrm{~m}$ using average thermal diffusivities over a wide range of soils at field capacity (de Vries and Afgan, 1975; Kuo, 1998). The depth $z_{T}$ at which soil temperatures were computed was set a priori using SSURGO data equal to the average depth of the soils in the watershed $(60 \mathrm{~cm})$. Reference temperature $T_{B F}$ for the baseflow export coefficient, Eq. (6), was set a priori to the amplitude of the sine wave temperatures at depth $z_{T}\left(11^{\circ} \mathrm{C}\right)$.

Records kept by the collaborating farm supplied the number of manure loads applied on each field and each day for 1997 and 1998. While the data are the best available, the records were frequently vague, and the information somewhat approximate. Manure spreading was therefore simulated on a semi-distributed basis, as described above. According to the manure spreader calibration record, one load represents $7670 \mathrm{~kg}$ of manure and covers approximately $2000 \mathrm{~m}^{2}$ of land surface, or an application amount of $38350 \mathrm{~kg} \mathrm{ha}^{-1}$. Analysis of manure samples gave an average manure concentration of $0.56 \mathrm{gP} / \mathrm{kg}$ manure, hence about $4.3 \mathrm{~kg}$ per load or $21.5 \mathrm{~kg} \mathrm{ha}^{-1}$. The average fraction of water-extractable $\mathrm{P}$ available just after application was estimated a priori at $65 \%$, in accordance with Sharpley and Moyer (2000). Therefore, each load of manure corresponded to an initial mass of $2.8 \mathrm{~kg}$ of water-extractable $\mathrm{P}$, or $14.0 \mathrm{~kg} \mathrm{ha}^{-1}$. Following Nash et al. (2000), the exponential decay time $\tau$ in Eq. (10) was set a priori to 7 days. The characteristic manure TDP release volume $V_{m}$ was estimated a priori as $25 \mathrm{~mm}$ from Sharpley and Moyer (2000) and (Gérard-Marchant et al., 2005).

In translating hydrology to $\mathrm{P}$ transport we have attempted to rely on relationships derived from physical processes, in order to make the model have the largest range of possible application. However, each landscape behaves in its own particular way according to the highly variable nature of soil, bedrock, topography, vegetation, and farm management that control hydrologic and $\mathrm{P}$ loading processes. The manurerelated $\mathrm{P}$ loading function is expected to be transferable, and is in fact based upon data from manure extraction studies in Pennsylvania. Users must estimate an initial manure P concentration and monitor the amount of rainfall and timing of application. In the case of surface runoff, the initial relationship between soil test $\mathrm{P}$ and $\mathrm{P}$ concentrations in runoff was derived on a site specific basis from simulated rainfall data (Hively et al., 2005). Considerable research has demonstrated that the relationship between soil test $\mathrm{P}$ and $\mathrm{P}$ in runoff is consistent, but only within soil types, and it is recommended that this relationship be established on a local basis (Kleinman et al, 2000; Sharpley et al., 2002, 2003). Such,

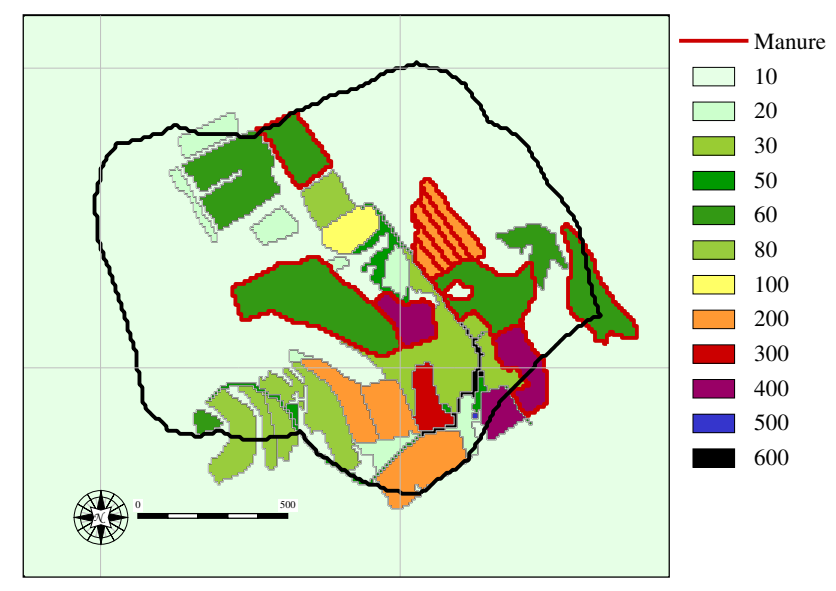

Fig. 2. Extraction coefficients map of the study watershed. Units: $\left[\mu \mathrm{gl}^{-1}\right]$. Regularly manured areas outlined in red. Watershed boundary outlined in black.

unfortunately, appears to be the nature of soil $\mathrm{P}$ loading processes, due to the inherent effects of particle size distribution and iron/aluminum content upon soil charge and $\mathrm{P}$ sorption capacity. That said, the coefficients derived in this model are likely applicable to soils throughout the Catskill landscape that comprises the New York City watersheds.

\section{Results and discussion}

Daily predicted TDP loads for the watershed were calculated as the sum of TDP transported in flow from each gridcell via the four model components (non-manure covered soils, baseflow,manure-covered areas, and impermeable near-barn areas). These values were subsequently compared to the daily observed loads that were recorded at the watershed outlet. Tables 2 and 3 compare the observed and simulated TDP loads over the simulated period, along with the values of various efficiency criteria: standard Nash-Sutcliffe efficiency criterion NS (Nash and Sutcliffe, 1970), modified Nash-Sutcliffe criterion MSN (Chiew and McMahon, 1994), mean absolute error MAE (Ye et al., 1997), and correlation coefficients $\mathrm{R}^{2}$.

As shown in Fig. 3, the timing of the load peaks was in most cases well reproduced, except on some winter dates (e.g. 15 January 1997, 6 February 1997, 17 January 1998) where flow and load peaks were missed. This discrepancy was attributed to imperfect modeling of snowmelt events, and to the use of offsite climate input data that did not reflect the actual localized on-site precipitation. During the winter, TDP load peaks were usually underestimated but overall flow volumes were generally correct. The simulated TDP loads matched well with the observed data during winter low flow events. During summer, however, loads corresponding to low-flow events were underestimated. It should be 
Table 2. Comparison of annual, summer and winter values of observed and simulated daily TDP loads and efficiency criteria for the simulated period (1 January 1997-31 December 1998).

\begin{tabular}{lcccccc}
\hline & \multicolumn{3}{c}{ With $\mathrm{Q}_{10}$ correction } & \multicolumn{3}{c}{ No $\mathrm{Q}_{10}$ correction } \\
\hline All data & All & $\mathbf{1 9 9 7}$ & $\mathbf{1 9 9 8}$ & All & $\mathbf{1 9 9 7}$ & $\mathbf{1 9 9 8}$ \\
Obs. Loads [g] & 58213 & 20306 & 37907 & 58213 & 20306 & 37907 \\
Sim. Loads [g] & 44645 & 20483 & 24162 & 98200 & 45491 & 52709 \\
Obs. Flows [mm] & 976 & 424 & 552 & & & \\
Simul. flows [mm] & 944 & 424 & 520 & & & \\
NS $^{1}$ & 0.39 & -0.22 & 0.48 & -0.02 & -3.01 & 0.46 \\
MNS & 0.51 & 0.30 & 0.58 & 0.15 & -0.59 & 0.46 \\
MAE & 0.38 & 0.20 & 0.47 & 0.01 & -0.55 & 0.28 \\
$\mathrm{R}^{2}$ & 0.40 & 0.30 & 0.54 & 0.49 & 0.38 & 0.60 \\
Summer data (1 May-31 Oct.) & & & & & & \\
Obs. Loads [g] & 18597 & 5191 & 13406 & 18597 & 5191 & 13406 \\
Sim. Loads [g] & 17839 & 7655 & 10184 & 24166 & 10636 & 13530 \\
Obs. Flows [mm] & 236 & 73 & 163 & & & \\
Sim. flows [mm] & 197 & 76 & 121 & & & \\
NS ${ }^{1}$ & 0.42 & -1.36 & 0.67 & 0.20 & -3.03 & 0.67 \\
MNS & 0.57 & 0.08 & 0.71 & 0.43 & -0.35 & 0.68 \\
MAE & 0.45 & 0.05 & 0.56 & 0.28 & -0.43 & 0.50 \\
$\mathrm{R}^{2}$ & 0.50 & 0.51 & 0.69 & 0.48 & 0.58 & 0.67 \\
Winter data & & & & & & \\
Obs. Loads [g] & 39616 & 15115 & 24502 & 39616 & 15115 & 24502 \\
Sim. Loads [g] & 26806 & 12828 & 13978 & 74034 & 34856 & 39179 \\
Obs. Flows [mm] & 740 & 351 & 389 & & & \\
Sim. flows [mm] & 747 & 348 & 399 & & & \\
NS & 0.36 & -0.02 & 0.41 & -0.12 & -3.48 & 0.38 \\
MNS & 0.40 & 0.16 & 0.49 & -0.12 & -1.32 & 0.31 \\
MAE & 0.32 & 0.14 & 0.41 & -0.17 & -0.84 & 0.16 \\
$\mathrm{R}^{2}$ & 0.39 & 0.23 & 0.51 & 0.47 & 0.26 & 0.60 \\
\hline
\end{tabular}

1. Nash-Sutcliffe criterion (Nash and Sutcliffe, 1970)

2. Modified Nash Sutcliffe criterion (Chiew and McMahon, 1994)

3. Mean Absolute Error (Ye et al., 1997)

noted that when the calculation of efficiency criteria was restricted to days when predicted flow matched observed flow by $+/-25 \%$, then the model accuracy improved substantially (e.g., $\mathrm{R}^{2}$ values increased from 0.39 to 0.62 on the total period), as presented in Table 3, reflecting the fact that if the hydrology is not accurately modeled, the $\mathrm{P}$ loading will be in error.

Implementing the $\mathrm{Q}_{10}$ temperature modification to the estimated TDP export coefficients resulted in noticeable improvements in the predicted TDP load values, as illustrated in Fig. 3 and Table 2. In particular, the decrease of baseflow concentration $c_{B F}$ and soil release concentrations $c_{S}$ with decreased temperature substantially improved the match between predicted and observed TDP loads during winter lowflow events. However, this improvement had little effect on the various efficiency criteria, suggesting that these criteria may not be very effective for evaluating model performance.

The first difficulty of validation is that if hydrology is not accurately simulated, P loading, which is directly de- pendent on hydrologic estimates, will be inaccurate. Therefore, the derived measures of fit were significantly better for days when hydrology was simulated within $25 \%$ of measured flow. The observed dataset is one of the most complete available in the nation, and provides an excellent daily estimate of actual $\mathrm{P}$ loads. Although it is difficult to aggregate landscape source factors for comparison with loads measured at a single outlet, this is a difficulty faced in common by all models. The main of the SMDR P Load Model in this case is that the estimated concentrations were carefully derived from a wide variety of on site measurements (Hively, 2004), and the validation data is therefore as good as any.

\subsection{Relative importance of model components}

The relative contributions of each TDP transport component (baseflow, overland flow from soils, from manured areas, and from impervious areas) are reported in Table 4. Overall, predicted total TDP loads delivered from the watershed were 
Table 3. Comparison of efficiency criteria of the temperature corrected simulations, for (a) simulated flows matching observed flows $+/-25 \%$; (b) all flows.

\begin{tabular}{|c|c|c|c|c|c|c|}
\hline & \multicolumn{3}{|c|}{ Well-simulated flows 1} & \multicolumn{3}{|c|}{ All flows } \\
\hline & All & 1997 & 1998 & All & 1997 & 1998 \\
\hline \multicolumn{7}{|l|}{ Annual } \\
\hline Number of data points & 209 & 124 & 85 & 730 & 365 & 365 \\
\hline $\mathrm{NS}^{2}$ & -0.67 & -0.07 & -0.83 & 0.39 & -0.22 & 0.48 \\
\hline $\mathrm{MNS}^{3}$ & 0.34 & 0.28 & 0.37 & 0.51 & 0.3 & 0.58 \\
\hline $\mathrm{MAE}^{4}$ & 0.13 & 0.15 & 0.14 & 0.38 & 0.2 & 0.47 \\
\hline $\mathrm{R}^{2}$ & 0.62 & 0.25 & 0.71 & 0.4 & 0.3 & 0.54 \\
\hline \multicolumn{7}{|c|}{ Summer (1 May-31 October) } \\
\hline Number of data points & 73 & 44 & 29 & 368 & 184 & 184 \\
\hline $\mathrm{NS}^{2}$ & 0.86 & 0.43 & 0.96 & 0.42 & -1.39 & 0.67 \\
\hline $\mathrm{MNS}^{3}$ & 0.77 & 0.55 & 0.92 & 0.57 & 0.08 & 0.71 \\
\hline $\mathrm{MAE}^{4}$ & 0.62 & 0.42 & 0.76 & 0.45 & 0.05 & 0.56 \\
\hline $\mathrm{R}^{2}$ & 0.87 & 0.5 & 0.96 & 0.5 & 0.51 & 0.69 \\
\hline \multicolumn{7}{|c|}{ Winter (1 January-31 March, 1 November-31 December) } \\
\hline Number of data points & 136 & 80 & 56 & 362 & 181 & 181 \\
\hline $\mathrm{NS}^{2}$ & -2.79 & -0.76 & -3.32 & 0.36 & -0.02 & 0.41 \\
\hline $\mathrm{MNS}^{3}$ & -0.23 & -0.12 & -0.32 & 0.4 & 0.16 & 0.49 \\
\hline $\mathrm{MAE}^{4}$ & -0.49 & -0.25 & -0.61 & 0.32 & 0.14 & 0.41 \\
\hline $\mathrm{R}^{2}$ & 0.79 & 0.2 & 0.94 & 0.39 & 0.23 & 0.51 \\
\hline
\end{tabular}

$1 \mid 1-$ Qsim/Qobs $\mid<0.25$

2 Nash-Sutcliffe criterion (Nash and Sutcliffe, 1970)

3 Modified Nash Sutcliffe criterion (Chiew and McMahon, 1994)

${ }^{4}$ Mean Absolute Error (Ye et al., 1997)

Table 4. Contributions of each TDP transport component to the total TDP load.

\begin{tabular}{lcccccc}
\hline & \multicolumn{3}{c}{ TDP loads [g] } & \multicolumn{5}{c}{ Contributions [\%] } \\
\hline & Observed & Total & $\mathrm{D}_{<B F>}^{2}$ & $\mathrm{D}_{<S>}^{2}$ & $\mathrm{D}_{<I A>}^{2}$ & $\mathrm{D}_{<M>}^{2}$ \\
1997+1998 & 58213 & 44645 & 30.1 & 48.1 & 13.9 & 07.9 \\
Summer $^{1}$ & 18597 & 17839 & 33.4 & 31.4 & 18.4 & 16.8 \\
Winter $^{1}$ & 39616 & 26806 & 27.8 & 59.3 & 11 & 01.9 \\
& & & & & & \\
1997 & 20306 & 2048 & 27.5 & 45.2 & 13.1 & 14.2 \\
Summer & 5191 & 7655 & 24.5 & 27.2 & 16 & 32.3 \\
Winter & 15115 & 1828 & 29.2 & 56 & 11.4 & 03.4 \\
& & & & & & \\
1998 & 37907 & 24162 & 32.3 & 50.6 & 14.6 & 02.5 \\
Summer & 13406 & 10184 & 40.1 & 34.6 & 20.2 & 05.1 \\
Winter & 24502 & 13978 & 26.6 & 62.3 & 10.5 & 00.6 \\
\hline
\end{tabular}

${ }^{1}$ Summer: 1 May-31 October; Winter: 1 January-30 April, 1 November-31 December

${ }^{2}$ BF: baseflow; S: Soils; IA: Impervious areas; M: Manure covered areas

dominated by the effect of overland flow from soils without recent manure application ( $48 \%$ of total loading). The greater contribution of soils during winter vs. summer (Table 4) is likely attributable to the greater extent of saturated areas during winter months, while in summertime runoff pro- duction is often concentrated in non-field areas such as slopebreaks, groundwater springs, and impervious areas (Hively et al., 2005). The predicted contribution of TDP from manurecovered soils was overall less than $10 \%$ of total loads for the entire simulation period. However, the relative contribution 

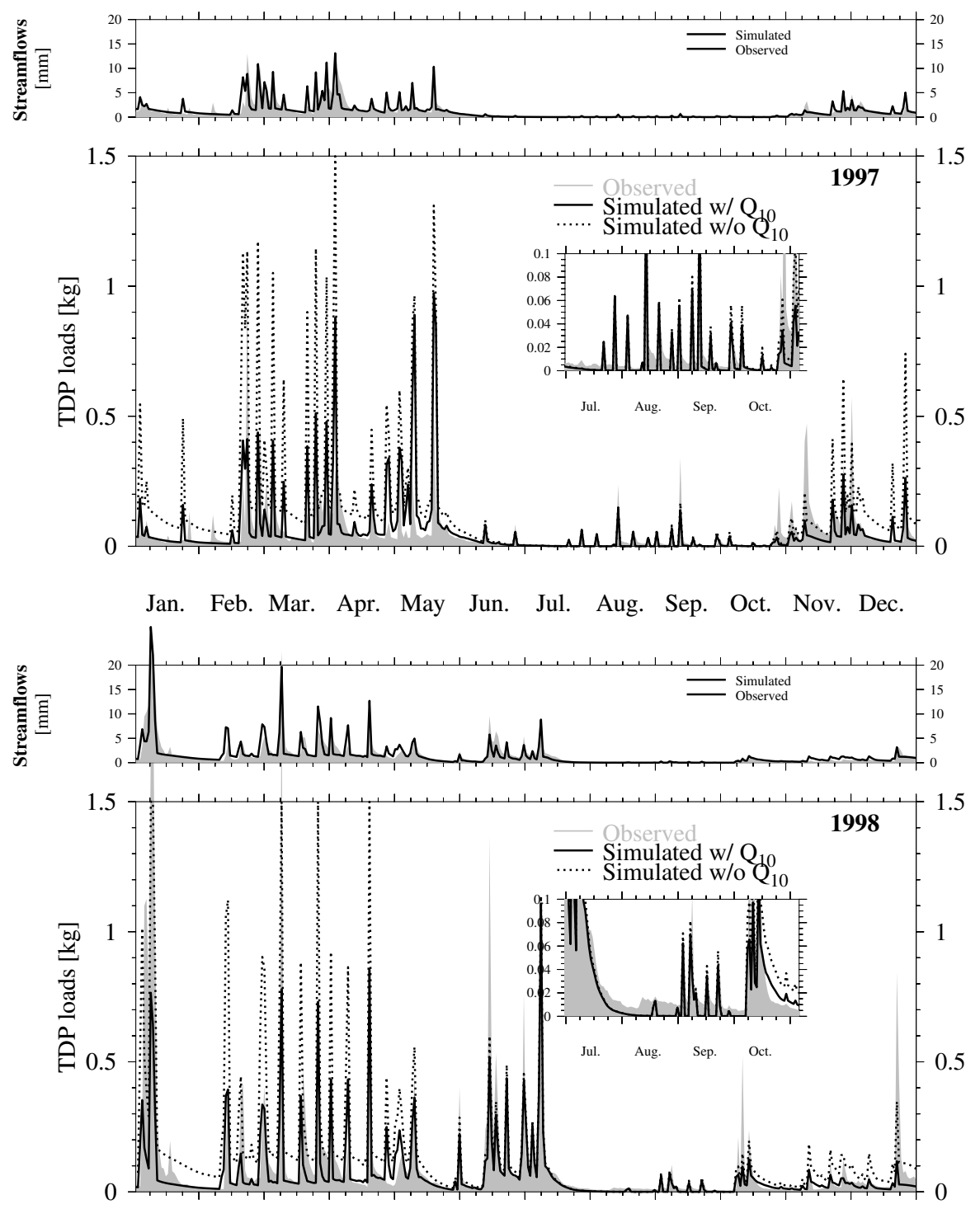

Jan. Feb. Mar. Apr. May Jun. Jul. Aug. Sep. Oct. Nov. Dec.

Fig. 3. Comparison of observed and simulated total dissolved phosphorus (TDP) loads. For a description of the $\mathrm{Q}_{10}$ modification, see Eq. (6).

of manured areas varied greatly with time, with almost no contribution during most of the year, to a monthly average of 25\% in April and May, with maximum contributions up to $90 \%$ on some days of these months. This "encouraging" observation may reflect the efficiency of the manure best management practices implemented on the farm, with no manure spread from November to April and reduced spreading on hydrologically sensitive areas. The estimation of $\mathrm{P}$ contribution from manured areas could be improved by field testing the algorithm for modeling TDP loss from manure, since it was derived from off-site experimental results (Sharpley and Moyer, 2000; Gérard-Marchant et al., 2005). Moreover, TDP losses from manure are modeled on a semi-distributed basis: a fully distributed modeling of manure application could be attained if GPS data were recorded by the spreader unit.

Predicted contributions from the impervious areas accounted for about $15 \%$ of the total loads over the 2-year simulation period, although the areas were of minor spatial extent ( $<2 \%$ of total watershed area). Here again, the contributions varied greatly with time. In summer and fall, transport of TDP from impervious areas represented up to $95 \%$ of the daily loads. During this period, the watershed tends to be dry, and most runoff occurs from direct precipitation on roads and near barn area. Reciprocally, during winter, when the contribution of roadways to runoff production is small compared to saturation-excess and when cows did not travel 
to pastures, the relative contribution of impervious areas to TDP transport was small.

\subsection{A call for further improvements}

The preliminary model results are encouraging, because the model performed well with minimal calibration. However, there is room for improvement. First, a considerable amount of error in TDP load prediction resulted from error in SMDRpredicted flow volumes. The summer baseflows were underestimated (Gérard-Marchant et al., 2006), resulting in the underestimation of TDP loads during summer. Better results could be achieved with improvements in the hydrology of SMDR itself.

Some aspects of the TDP transport model itself could be improved as well. For example, summertime manure deposition on fields, or directly in streams, by the grazing herd is not currently considered, although results of rainfall simulation have indicated increased $\mathrm{P}$ loss following intensive grazing (Hively, 2004; Hively et al., 2005). If accurate grazing records were available, pasture and impervious area manure deposition could be directly implemented into the current model, using a modification of the algorithm currently used for manure-covered soils. A simpler approach would consist of allocating a variable release coefficient to each grazed cell. Finally, improved characterization of P loss from nearbarn impervious areas could be attained through monitoring of manure deposition and roadway STP.

\section{Summary and conclusion}

A distributed model for the simulation of total dissolved phosphorus (TDP) in watershed runoff was developed and implemented. The Soil Moisture Distribution and Routing model (SMDR) provided daily estimates of distributed runoff production. Estimated TDP concentrations in base flow and runoff from non-manured fields were simulated with extraction coefficients adjusted for temperature with an Arrhenius type of equation. Estimated TDP concentrations from manured fields were simulated based on water soluble $\mathrm{P}$ in the manure. Estimated TDP losses from impervious areas with manure were simulated with seasonal extraction coefficients. The model was tested for a two year period when the manure spreading schedule was known for a watershed dairy farm. Observed TDP loads at the watershed stream outlet were reasonably well simulated when the temperature correction was taken into account. The TDP losses were largely controlled by transport of soil $\mathrm{P}$ by overland flow from non-manure covered soils. Phosphorus loss from manured fields was about $10 \%$ of total TDP losses on average, with the greatest contributions occurring in April and May, during the period that the winter-stored manure was spread and the extent of runoff producing areas was large.
Most of the differences between observed and simulated loads were attributed to an imperfect reproduction of the hydrological components. Improvements in the estimation of percolation and snowmelt would improve predictions during summer and winter periods respectively.

Although the actual implementation of the soil TDP extraction model relies strongly on the accurate spatial distribution of runoff generating areas, the model performance was evaluated by comparing simulated and observed flows and TDP loads summed over the entire watershed. Limitations in experimental data prevent the validation on a distributed basis. Despite this limitation, this simple P loading model provides an adequate starting point for the estimation of lumped TDP losses for various landscape areas and land uses and can be used in realistic manner to evaluate the effects of best management practices.

Acknowledgements. The United States Departments of Agriculture and Interior provided primary funding for this study. The grant of the Department of Interior was administered by the Water Resources Institute Additional funding was provided by the United States Department of Environmental Protection under the Safe Drinking Water Act, administered by the Watershed Agricultural Council (WAC). The data for validation was obtained from P. Bishop of the New York State Department of Environmental Conservation (NYSDEC). M. R. Rafferty, J. L. Lojpersberger of NYSDEC and S. Pacenka of WRI are acknowledged for the collecting and/or modification this data. In addition we would like to thank the members of the Town Brook Research Group, Watershed Agricultural Program Planners and Landowners for their invaluable discussions on and insights in watershed processes in the Catskill Mountains. Specifically we would like to thank the collaborating farm family for their willingness to participate in the research effort and their patience in dealing with us.

Edited by: N. Romano

\section{References}

Akhtar, M. S., Richards, B. K., Medrano, P. A., DeGroot, M., and Steenhuis, T. S.: Dissolved phosphorus losses from undisturbed soil cores: related to adsorption strength, flow rate, or soil structure, Soil Sci. Soc. Amer. J., 67, 458-470., 2003.

Arnold, J. G., Allen, P. M., and Bernhardt, G.: A comprehensive surface-groundwater flow model, J. Hydrol., 142, 47-69, 1993.

Arnold, J. G., Williams, J. R., Srinivasan, R., King, K. W., and Griggs, R. H.: SWAT, Soil and Water Assessment Tool, USDA, Agriculture Research Service, Temple, TX 76502., 1994.

Beauchemin, S., Simard, R. R., and Cluis, D.: Phosphorus sorptiondesorption kinetics of soil under contrasting land uses, J. Environ. Quality, 25, 1317-1325, 1996.

Beven, K. J.: A discussion of distributed hydrological modelling, in: Distributed Hydrological Modelling, edited by: Abbott, M. and Refsgaard, J., Kluwer, Dordrecht, NL, 255-277, 1996.

Beven, K. J. and Kirkby, M. J.: A physically based, variable contributing area model of basin hydrology, Hydrol. Sci. Bull., 24(1), 43-69., 1979. 
Bishop, P. L., Hively, W. D., Stedinger, J. R., Bloomfield, J. A., Rafferty, M. R., and Lojpersberger, J. L.: Multivariate analysis of paired watershed data to evaluate agricultural BMP effects on stream water phosphorus, J. Environ. Quality, 34(3), 1087-1101, 2005.

Bishop, P. L., Rafferty, M., and Lojpersberger, J.: Event based water quality monitoring to determine effectiveness of agricultural BMPs, in: Proceedings of the American Water Resources Association 2003, International Congress on Watershed Management for Water Supply Systems, 29 June-2 July 2003, 2003.

Brown, M. P., Longabucco, P., Rafferty, M. R., Robillard, P. D., Walter, M. F., and Haith, D. A.: Effects of animal waste control practices on non-point source phosphorus loading in the west branch of the Delaware river watershed, J. Soil and Water Conservation, 44(1), 67-77, 1989.

Brutsaert, W. H.: Evaporation into the Atmosphere, D. Reidel Kluwer, Boston, MA, 1982

Bunnell, F. L., Tait, D. E. N., Flanagan, P. W., and Van Cleve, K.: Microbial respiration and substrate weight loss. I. a general model of the influences of abiotic variables, Soil Biol. Biochem., 9, 33-40, 1977.

Carpenter, S. R., Caraco, N. F., Corell, D. L., Howarth, R. W., Sharpley, A. N,and Smith, V. H.: Nonpoint pollution of surface waters with phosphorus and nitrogen, Ecol. Appl., 8, 559-568, 1998.

Cassell, E. A., Dorioz, J. M., Kort, R. L., Hoffmann, J. P., Meals, D. W., Kirschtel, D., and Braun, D. C.: Modeling phosphorus dynamics in ecosystems: mass balance and dynamic simulation approaches, J. Environ. Quality, 27, 293-298, 1989.

Chiew, F. H. S. and McMahon, T. A.: Application of the daily rainfall-runoff model MODHYDROLOG to 28 Australian catchments, J. Hydrol., 153, 383-416, 1994.

Clesceri, N. L., Curran, S. J., and Sedlak, R. L.: Nutrient loads to Wisconsin lakes: Part I. nitrogen and phosphorus export coefficients, Water Resources Bull., 22(6), 983-990, 1986.

Correll, D. L., Jordan, T. E., and Weller, D. E.: Effects of precipitation and air temperatures on phosphorus fluxes from Rhode River watersheds, J. Environ. Quality, 28, 144-154, 1999.

Cox, F. R. and Hendricks, S. E.: Soil test phosphorus and clay content effects on runoff water quality, J. Environ. Quality, 29, 15821586, 2000.

de Vries, D. A.: Thermal properties of soils, in: Physics of Plant Environment, edited by: van Wijk, W., North Holland Pub. Co., Amsterdam, NL, 210-235, 1963.

de Vries, D. A. and Afgan, N. H.: Heat and mass transfer in the biosphere, John Wiley and Sons, New York, NY, 1975.

DiLuzio, M. and Arnold, J. G.: Formulation of a hybrid calibration approach for a physically based distributed model with NEXRAD data input, J. Hydrol., 298, 136-154, 2004.

Dunne, T. and Black, R. D.: Partial area contributing to storm run off in a small New-England watershed, Water Resources Research, 6(5), 1296-1311, 1970.

Dunne, T., Moore, T. R., and Taylor, C. H.: Recognition and prediction of runoff-producing zones in humid regions, Hydrol. Sci. Bull., 20(3), 305-327, 1975.

Edwards, D. R., Daniel, T. C. Drying interval effects on runoff from fescue plots receiving swine manure, Trans. ASAE, 36, 16731678, 1993a.

Edwards, D. R. and Daniel, T. C.: Effects of litter application rate and rainfall intensity on quality of runoff from fescue grass plots, J. Environ. Quality, 22, 361-365, 1993b.

Fozzard, I. R., Doughty, C. R., Ferrier, R. C., Leatherland, T. M., and Owen, R.: A quality classification for management of Scottish standing waters, Hydrobiologia, 395-396, 433-455, 1999.

Frankenberger, J. R., Brooks, E. S., Walter, M. T., Walter, M. F., and Steenhuis, T. S.: A GIS-based variable source area hydrology model, Hydrol. Proc., 13(6), 805-822, 1999.

Frossard, E., Condron, L. M., Oberson, A., Sinaj, S., and Fardeau, J. C.: Process governing phosphorus availability in temperate soils, J. Environ. Quality, 29(1), 15-23, 2000.

Gächter, R., Ngatiah, J., and Stamm, C.: Transport of phosphate from soil to surface waters by preferential flow, Environ. Sci. and Technol., 32(13), 1865-1869, 1998.

Gascho, G. J., Wauchope, R. D., Davis, J. G., Truman, C. C., Dowler, C. C., Hook, J. E., Sumner, H. R., and Johnson, A. W.: Nitrate-nitrogen, soluble, and bioavailable phosphorus runoff from simulated rainfall after fertilizer application, Soil Sci. Soc. of America Journal, 62, 1711-1718, 1998.

Gburek, W. J., Sharpley, A. N., and Pionke, H.: Identification of critical source areas for phosphorus export from agricultural catchments, in: Advances in Hillslope Processes, edited by: Anderson, M. and Brookes, S., John Wiley \& Sons, Chichester, UK, 263-282, 1996.

Geohring, L. D., McHugh, O. V., Walter, M. T., Steenhuis, T. S., Akhtar, M. S., and Walter, M. F.: Phosphorus transport into subsurface drains by macropores after manure applications: implications for best manure management practices, Soil Sci., 166, 896-909, 2001.

Gérard-Marchant, P., Walter, M. T., and Steenhuis, T. S.: Simple models for phosphorus loss from manure in runoff, J. Environ. Quality, 34(3), 872-876, 2005.

Gérard-Marchant, P., Hively, W. D., and Steenhuis, T. S.: Distributed hydrological modeling of total dissolved phosphorus transport in an agricultural landscape, part I: Runoff generation, Hydrol. Earth Syst. Sci., 10, 245-261, 2006.

Ginting, D., Moncrief, J. F., Gupta, S. C., and Evans, S. D.: Interaction between manure and tillage system on phosphorus uptake and runoff losses, J. Environ. Quality, 27, 1403-1410, 1998.

Gupta, A., Destouni, G., and Jensen, M. B.: Modeling tritium and phosphorus transport by preferential flow in structured soil, J. Contaminant Hydrol., 35(4), 389-407, 1999.

Haith, D. A., Mandel, R., and Wu, R. S.: Generalized watershed loading functions version 2.0: User's manual, Technical Report, Department of Agricultural and Biological Engineering, Cornell University, Ithaca, NY, 1992.

Haith, D. A. and Shoemaker, L. L.: Generalized watershed loading functions for stream flow nutrients, Water Resour. Bull., 23, 471478, 1987

Hanrahan, G., Gledhill, M., House, W. A., and Worsfold, P. J.: Phosphorus loading in the Frome catchment, UK: Seasonal refinement of the coefficient modeling approach, J. Environ. Quality, 30, 1738-1746, 2001.

Hansen, N. C., Daniel, T. C., Sharpley, A. N., and Lemunyon, J. L.: The fate and transport of phosphorus in agricultural systems, J. Soil Water Conserv., 57(6), 408-417, 2002.

Haygarth, P. and Sharpley, A. N.: Terminology for phosphorus transfer, J. Environ. Quality, 29(1), 10-15, 2000.

Hewlett, J. D. and Hibbert, A. R.: Factors affecting the response 
of small watersheds to precipitation in humid regions, in: Forest hydrology, edited by: Sopper, W. E. and Lull, H. W., Pergamon Press, Oxford, UK, 275-290, 1967.

Hewlett, J. D. and Nutter, W. L.: The varying source area of streamflow from upland basins, in: Proceedings of the Symposium on Interdisciplinary Aspects of Watershed Management, 6 August 1970, ASCE, Bozeman, MT, 65-83, 1970.

Hively, W. D.: Phosphorus loading from a monitored dairy farm landscape, $\mathrm{PhD}$ dissertation, Cornell University, Ithaca, NY, USA, 2004.

Hively, W. D., Bryant, R. B., and Fahey, T. J.: P concentrations in overland flow from diverse locations on a New York dairy farm, J. Environ. Quality, 34(4), 2005.

Hooda, P. S., Moynagh, M., Svoboda, I. F., Edwards, A. C., Anderson, H. A., and Sym, G.: Phosphorus loss in drainflow from intensively managed grassland soils, J. Environ. Quality, 28, 12351242, 1999.

Horton, R. E.: The role of infiltration in the hydrological cycle, Transactions of the American Geophysical Union, 14, 446-460, 1933.

Horton, R. E.: An approach toward a physical interpretation of infiltration capacity, Soil Sci. Soc. Amer. Proc., 4, 399-418, 1940.

Johnson, M. S., Coon, W. F., Mehta, V. K., Steenhuis, T. S., Brooks, E. S., and Boll, J.: Application of two hydrologic models with different runoff mechanisms to a hillslope dominated watershed in the northeastern US: a comparison of HSPF and SMR, J. Hydrol., 284, 57-76, 2003.

Johnsson, H., Bergstrom, L., and Jansson, P.-E.: Simulated nitrogen dynamics and losses in a layered agricultural soil, Agriculture, Ecosystems, and Environment, 18, 333-356, 1987.

Kingery, W. L., Wood, C. W., and Williams, J. C.: Tillage and amendment effects on soil carbon and nitrogen mineralization and phosphorus release, Soil and Tillage Res., 37(4), 239-250, 1996.

Klatt, J. G., Mallarino, A. P., Downing, J. A., Kopaska, J. A., and Wittry, D. J.: Soil phosphorus, management practices, and their relationship to phosphorus delivery in the Iowa Clear Lake Agricultural watershed, J. Environ. Quality, 23(6), 2140, 2003.

Kleinman, P. J. A.: Source risk indicators of nutrient loss from agricultural lands, in: Managing nutrients and pathogens in animal agriculture, edited by: Sailus, M., Northeast Regional Agricultural Engineering Service, Ithaca, NY, 237-252, 2000.

Kleinman, P. J. A., Bryant, R. B., and Reid, W. S.: Development of pedotransfer functions to quantify phosphorus saturation of agricultural soils, J. Environ. Quality, 28, 2026-2030, 1999.

Kleinman, P. J. A., Bryant, R. B., Reid, W. S., Sharpley, A. N., and Pimentel, D.: Using soil phosphorus behavior to identify environmental thresholds, Soil Sci., 165(12), 943-950, 2000.

Kleinman, P. J. A. and Sharpley, A. N.: Effect of broadcast manure on runoff phosphorus concentrations over successive rainfall events, J. Environ. Quality, 32, 1072-1081, 2003.

Koopmans, G. F., Chardon, W. J., Ehlert, P. A. I., Dolfing, J., Suurs, R. A. A., Oenemaa, O., and van Riemsdijk, W. H.: Phosphorus availability for plant uptake in a phosphorus-enriched noncalcareous sandy soil, J. Environ. Quality, 33, 965-975, 2004.

Kuo, W.-L.: Spatial and temporal analysis of soil water and nitrogen distribution in undulating landscapes using a GIS-based model, PhD dissertation, Cornell University, Ithaca, NY, USA, 1998.

Kuo, W.-L., Steenhuis, T. S., McCulloch, C. E., Mohler, C. L., We- instein, D. A., DeGloria, S. D., and Swaney, D. P.: Effect of grid size on runoff and soil moisture for a variable-source-area hydrology model, Water Resour. Res., 35, 3419-3428, 1999.

Lathwell, D. J., and Peech, M.: Interpretation of chemical soil tests, Cornell Univ. Agric. Exp. Stn. Bull., 995, Cornell Univ., Ithaca, NY, 1965.

Maguire, R. O. and Sims, J. T.: Soil testing to predict phosphorus leaching, J. Environ. Quality, 31, 1601-1609, 2002.

McDowell, R. W. and Sharpley, A. N.: Approximating phosphorus release from soils to surface runoff and subsurface drainage, J. Environ. Quality, 30(2), 508-520, 2001.

McDowell, R. W. and Sharpley, A. N.: Availability of residual phosphorus in high phosphorus soils, Communications in Soil Science and Plant Analysis, 33(7-8), 1235-1246, 2002a.

McDowell, R. W. and Sharpley, A. N.: The effect of antecedent soil moisture conditions on sediment and phosphorus loss during overland flow: Mahantango Creek catchment, Pennsylvania, Hydrol. Proc., 16(5), 3037-3050, 2002b.

McDowell, R. W. and Sharpley, A. N.: Phosphorus solubility and release kinetics as a function of soil test $\mathrm{P}$ concentration, Geoderma, 112(1-2), 143-154, 2003.

Mehta, V. K., Walter, M. T., Brooks, E. S., Steenhuis, T. S., Walter, M. F., Johnson, M. S., Boll, J., and Thongs, D.: Application of SMR to modeling watersheds in the Catskills mountains, Environmental Modeling and Assessment, 9, 77-89, 2004.

Morel, C., Tunney, H., Plénet, D., and Pellerin, S.: Transfer of phosphorus ions between soil and solution: perspectives in soil testing, J. Environ. Quality, 29, 50-59, 2000.

Nash, D., Hannah, M., Halliwell, D., and Murdoch, C.: Factors affecting phosphorus transport from a pasture-based grazing system, J. Environ. Quality, 29(4), 1160-1166, 2000.

Nash, J. E. and Sutcliffe, J. V.: River flow forecasting through conceptual models, part I - a discussion of principles, J. Hydrol., 10, 238-250, 1970.

NCDC: Climatalogical data annual summary - New York, National Climate Data Center (NCDC), Asheville, NC, 2000.

Needelman, B. A., Gburek, W. J., Petersen, G. W., Sharpley, A. N., and Kleinman, P. J. A.: Surface runoff along two agricultural hillslopes with contrasting soils, Soil Sci. Soci. Amer. Journal, 68, 914-923, 2004.

Neitsch, S. L., Arnold, J. G., Kiniry, J. R., William, J. R., and King, K. W.: SWAT- Soil and Water Assessment Tool 2000 - Theoretical documentation, Temple, TX, 2002.

Pote, D. H., Daniel, T. C., Sharpley, A. N., Moore Jr, P. A., Edwards, D. R., and Nichols, D. J.: Relating extractable soil phosphorus to phosphorus losses in runoff, Soil Sci. Soc. Amer. Journal, 60, 855-859, 1996.

Randall, G. W., Iragavarapu, T. K., and Schmitt, M. A.: Nutrient losses in subsurface drainage water from dairy manure and urea applied for corn, J. Environ. Quality, 29(4), 1244-1252, 2000.

Robillard, P. D. and Walter, M. F.: Non-point source control of phosphorus, a watershed evaluation: Vol. i, phosphorus losses from dairy barnyard areas, Tech. rep., Robert S. Kerr Environmental Research Laboratory, ORD. USEPA, Ada, OK, 1984.

Ryden, J. C., Syers, J. K., and Harris, R. F.: Phosphorus in runoff and streams, Adv. Agronomy, 25(1), 1-45, 1973.

Schneiderman, E. M., Pierson, D. C., Lounsbury, D. G., and Zion, M. S.: Modeling the hydrochemistry of the Cannonsville watershed with Generalized Watershed Loading Functions (GWLF), 
J. Amer. Water Resour. Assoc., 38(5), 1323-1347, 2002.

Schoumans, O. F. and Groenendijk, P.: Modeling soil phopshorus levels and phosphorus leaching from agricultural land in the Netherlands, J. Environ. Quality, 29, 111-116, 2000.

Schroeder, P. D., Radcliffe, D. E., Cabrera, M. L., and Belew, C. D.: Relationship between soil test phosphorus and phosphorus in runoff: Effects of soil series variability, J. Environ. Quality, 33, 1452-1463, 2004.

Sharpley, A. N., Chapra, S., Wedepohl, R., Sims, J. T., Daniel, T. C., and Reddy, K.: Managing agricultural phosphorus for protection of surface waters: Issues and options, J. Environ. Quality, 23(3), 437-451, 1994

Sharpley, A. N., Daniel, T. C., Sims, J. T., and Pote, D. H.: Determining environmentally sound soil phosphorus levels, J. Soil Water Conserv., 51(2), 160-166, 1996.

Sharpley, A. N. and Kleinman, P. J. A.: Effect of rainfall simulator and plot scale on overland flow and phosphorus transport, J. Environ. Quality, 32(6), 2172-2179, 2003.

Sharpley, A. N., Kleinman, P. J. A, McDowell, R. W., Gitau, M., and Bryant, R. B.: Modeling phosphorus transport in agricultural watersheds: Processes and possibilities, J. Soil Water Conserv., 57, 425-439, 2002.

Sharpley, A. N, Meisinger, J., Breeuwsma, A., Sims, J. T., Daniel, T. C., and Schepers, J.: Impacts of animal manure management on ground and surface water quality, in: Effective management of animal waste as a soil resource, edited by: Hatfield, J., Ann Arbor Press, Chelsea, MI, 173-242, 1998.
Sharpley, A. N and Moyer, B.: Phosphorus forms in manure and compost and their release during simulated rainfall, J. Environ. Quality 29, 1462-1469, 2000.

Smith, C. and Monaghan, R. M.: Nitrogen and phosphorus losses in overland flow from a cattlegrazed pasture in southland, New Zealand J. Agric. Res., 46, 225-237, 2003.

Srinivasan, M. S., Gérard-Marchant, P., Veith, T. L., Gburek, W. J., and Steenhuis, T. S.: Watershed-scale modeling of criticalsource-areas of runoff generation and phosphorus transport, J. Am. Water Resour. Assoc, 41(2), 361-375, 2005.

Stamm, C., Fluhler, H., Gächter, R., Leuenberger, J., and Wunderli, H.: Preferential transport of phosphorus in drained grassland soils, J. Environ. Quality, 27(3), 515-522, 1998.

Wayland, K. G., Long, D. T., Hyndman, D. W., Pijanowski, B. C., Woodhams, S. M., and Haack, S. K.: Identifying relationships between baseflow chemistry and land use with synoptic sampling and R-mode factor analysis, J. Environ. Quality, 32, 180-190, 2003.

Ye, W., Bates, B. C., Viney, N. R., Silvapan, M., and Jakeman, A. J.: Performance of conceptual rainfall-runoff models in low yielding ephemeral catchments, Water Resour. Res., 33, 153-166, 1997. 